\title{
Absence, presence, remembrance: A theological essay on frailty, the university and the city
}

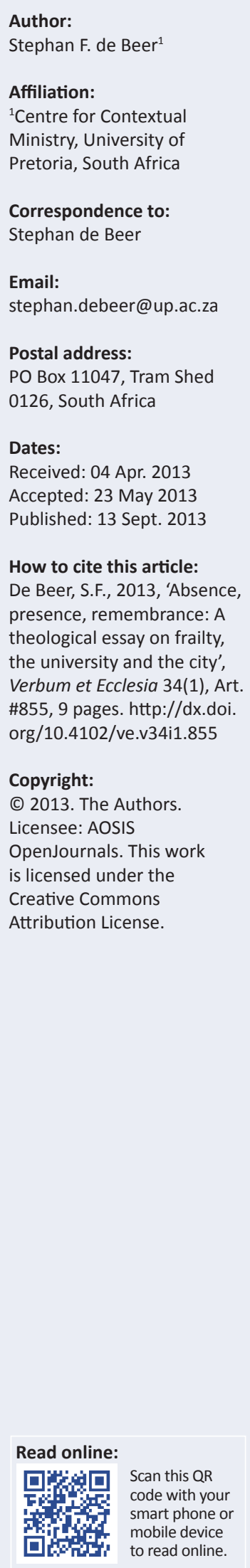

This essay is reflecting on frailty, the university and the city, in relation to each other. It seeks to transcend the binary concepts of presence and absence, proposing remembrance as the frail work of making absence present, of reweaving what is dismembered, and of a politics of hospitality. It considers the task of remembrance in the 'studio of life', disrupting or transcending the confines of laboratory and asylum.

\section{Introduction: Between city and university}

I write this reflection firstly for myself, carefully and deliberately seeking to hold on to different publics, seeking ways not to have to exchange one world of immersion for another, struggling between presence and absence, feeling slightly dismembered and trying to make sense of it.

I offer a reflection having in mind the community from which I come - whose members, at least some of them, are watching, some suspiciously, some in anticipation, to see whether the lives we lived and the commitments we made were merely rehearsed utterances, within a particular time and context, or, possibly, genuine articulations coming from deeper soul places and grounded commitments, confessing that this is where we stand, not because it was trendy or expected of us but because we could not do otherwise.

My recent journey took me from being deeply entrenched in inner-city neighbourhoods for 19 years - working alongside homeless people and girls at risk, working for access to housing and economic opportunity, working for our collective freedom and wholeness, both for us personally and for the neighbourhoods in which we lived - to the university campus.

Someone was reflecting with me to say 'I have not changed; my world has changed around me', suggesting that my core commitments to social justice and social inclusion do not have to change but will now be practiced from within another public or, rather, between different publics. And yet, to what extent does the world around me change me, for better or for worse, and to what extent are different presences or absences (different contexts) shaping the way I am, the way we are, the way we create spaces for a certain kind of knowledge to be developed and gained on a university campus?

This is an essay on absence, presence and remembrance, reflecting from within the context of a university campus, in relation to frailty and the broader context of the city which gives it a home.

\section{New insertion - into 'absence'}

It was in my 3rd week on the campus. I was still enjoying the euphoria of a green(er) environment and a different quieter rhythm. I still embraced the excitement of everything new and the opportunities it presented. I was thinking of how a friend described the main campus of the University as his 'escape fantasy'. I was sitting in what I soon discovered to be the 'second office' of the Faculty of Theology at Cafe Burgundy's. As I sat there in need of the only bit of sun on a cold May afternoon, it simply dawned on me that there were no children.

You hardly ever see children on campus, except for the occasional after-hour appearance at the Musaion for the annual Eisteddfod or some performance by music students or the occasional children entering the Department of Communication Pathology for assessments or therapy or maybe on the other side of the campus at the Science Lab. Generally, however, on most days, children are simply absent. And then, I realised that they were not the only ones. So are homeless people. Absent is the smell of poverty and abandonment. Mental disability, too, has little place on a university campus; this is a university after all, for the mentally 'competent', and 'insanity' is banished at the boom gates where you enter. 
One afternoon during my first 2 months, there was a visit by some institution for people with mental disabilities to what must have been a music performance at the Musaion. These rare visitors were indeed a curiosity as some passers-by openly stared at this 'spectacle' of otherwise 'neatly hidden away behind doors and walls and institutions' people, disturbing the neat landscape of the campus for a few hours one afternoon. The mirror to our own human frailty, so carefully put away, has been placed before us. There was no way to escape:

The ultimate language of madness is that of reason, but the language of reason enveloped in the prestige of the image, limited to the locus of appearance which the image defined. (Foucault 1965:95)

Suddenly it dawned on me that this reality is multiple 'absences'. In this laboratory of learning '[that] could be used as a machine to carry out experiments, to alter behaviour, to train and correct individuals' (Foucault 1979:203), the frailty we have to learn about and dissect and engage with has little place as 'the language of reason [is] enveloped in the prestige of image' (Foucault 1979:203). Feder (2011:60) reflects on Foucault's use of Panopticon as a laboratory, a 'privileged place for experiments on men [sic], and for analysing with complete certainty the transformations that may be obtained from them' (Foucault 1979:204).

I found this to be an insertion into absence. After a journey so deeply embedded in the vocation and language of presence, this new space was in stark contrast. It was layers of community in frail places, messiness, children, broken buildings and broken faces, people living with the anguish of mental illness, learning to be alongside without having any control and frailty not being masqueraded but stripped to the bone for all to see, the contrasts of scarcity and abundance, the ways in which bad power infiltrates shack communities and board rooms, churches and one's own organisation, relationships and intimacies - where presence were fleshed out, embodied, made frail in the presence of frailty. In the words of Foucault (1965):

Everything was organized so that the madman would recognize himself in a world of judgment that enveloped him on all sides; he must know that he is watched, judged, and condemned; from transgression to punishment, the connection must be evident, as a guilt recognized by all. (p. 266)

Carefully constructed, highly sanitised, securely and efficiently militarised space of highly independent and autonomous thinking; yet, within the narrow boundaries of carefully monitored car boots, computer screens, research plans, codes for doors, and individualised offices, the university campus is a 'small city', marked by the 'militarization of space' as described so aptly by Davis (1992b) in the chapter entitled Fortress Los Angeles: The militarization of urban space (see also Merrifield \& Swyngedouw 1997; De Beer 2008).

I started to feel the absence painstakingly presenting itself. I needed my children around, and when I brought them, they discovered and explored. I realised quickly that I might only dare bring them at strange hours, when everybody else had gone. When I broke my rule and risked bringing them earlier one day, the youngest one decided to do justice to this moment of presence by placing herself in a very strategic position in the passage way screaming at the top of her voice for no apparent reason until people looked cautiously from their doors to see whose child has been let loose.

This is the messiness of presence. This is why we have such strict rules for laboratories, I suppose. There has to be control. This is why a colleague reacted vehemently to my use of 'urban laboratory' as a potential positive metaphor for an urban educational space. It is because she has seen the laboratory for what it is - a sanitised space of experimenting on lifeless people and rats and things - within boundaries and without disturbances.

In the presence of the laboratory, there is absence of the chaos called life (Wikipedia n.d.[a]):

A laboratory (/la'borətəri/ or /'læbərətri/; informally, lab) is a facility that provides controlled conditions in which scientific research, experiments, and measurement may be performed. The title of laboratory is also used for certain other facilities where the processes or equipment used are similar to those in scientific laboratories.

\section{When absence is presence}

And yet, there comes a point when absence is presence. When absence becomes so glaring, so obvious and so painful, absence is transformed into a deeper, more tangible presence than presence itself (Bell n.d.). The presence of the inner city might not be physically surrounding me on the university campus, but its absence makes it glaringly present at times.

It is then that the deepest creativity is evoked to create signs or traces - representations or signifiers - of that which is not actually present, to help transcend the dichotomy of presence and absence (Ward 1995:151). Through representation, the other or the absent is perceived (Ward 1995:152-153, in reference to Levinas). 'Otherness is both re-presented in discourse and the absence that provokes discourse' (Ward 1995:153).

Absence provokes discourse. Absence demands being made present. Derrida speaks of this notion of Levinas as 'incarnation-as-disincarnation' (Ward 1995:153). It is an incarnation through representation without actual embodiment or immediacy of that which is absent. What is presented through representation is the absence of immediacy' (Ward 1995:153).

Is the cloud by night in the desert, accompanying God's post-exodus people, God's incarnation-as-disincarnation, a representation of God being present without the actual embodiment of God? When Barth speaks of knowledge of God, he suggests that what we know is the absence of God, and yet Barth speaks of it in positive terms, as the incomprehensiblitas Dei (Ward 1995:25) - the God who cannot 
be contained, manipulated or defined in human terms. This absent or hidden God is made present in the surprising encounter with the cloud by night or the sun by day, the burning bush or the breaking of bread, the stranger and particularly the unwanted and prejudiced stranger, the prisoner, the homeless person, the leper. They (and these) become the representations of God.

There is therefore never real absence in absence because the absence of immediacy is represented, sometimes by the absence itself, sometimes by the longing representing the absence, sometimes by the traces or signs thereof as in Derrida (cf. Wikipedia n.d.[b]).

And yet, will the people living in the informal settlements of Diepsloot or Kayelitsha feel their hearts strangely warmed at Derrida's suggestion - that it is in fact in their absence that they might become present? For would their representation, if at all, not always be secondary at best? Even those in the laboratory of the university campus, seeking to offer deliberate representations of that which is physically absent, can only offer feeble signs or traces, either of the One who heard our cries, who saw our pain and who decided to be in solidarity with us or of the many who are crying, who are in pain and who are systematically excluded from the conversation(s) of the laboratory.

\section{Different presences or absences}

This new insertion into absence, as I articulated it for myself, is not simply insertion into absence. It is neither absence nor presence. It is perhaps an absent presence and a present absence.

Both absence and presence are becoming a gift, to be embraced. In the longing to connect to that which is not here and in the longing to discover that which is, in the remembrance of both and in the embrace of a new insertion with new presences and absences and even in new frailties breaking through the carefully constructed laboratory, wildness and madness refusing to be tamed, frailty refusing to splinter into pieces, presences and absences creatively introduced and connected to each other, transcended and transformed, somewhere in here lies the différance, the sense of meaning, the gift of presence and absence.

This does not necessarily mean an apathetic surrender to what is or an idealistic remembrance of what was but a creative remembrance in the present, a pregnant remembrance, an imaginary remembrance with possibilities of new fusions. It is a remembrance of movements and moments beyond the sanitised laboratory and of movements and moments disturbing or disrupting the sanitised laboratory, inviting and evoking the asylum, sufficiently so to give glimpses that this presence is absence and that such absence could be disturbingly and invitingly present.

\section{When presence is absence}

From deeply personal experience, we know that presence can also be profound absence. Bodily presence can be accompanied by psychological or emotional absence (in relationships, spaces and classrooms). When our presences are conditional, controlling and manipulative, it speaks of an absence of connection, a disembodied presence. Many urban churches represent such a 'disembodied presence'. When we are present to each other in a way that does not truly create or allow space for 'the other', the insularity of our presence accentuates the absence of 'the other'. When our presence is so overwhelming that it overshadows the weaker voices of the poor, vulnerable girls, illegal asylum-seekers or informal street traders, it is a presence that should preferably have been kept at bay as it accentuates our strangeness, it becomes a 'heavy' presence, an unwanted presence. As such Derrida is right when he challenges the binary opposition of presence and absence as if presence is always better and absence worse.

It seems that both absence and presence could evoke a sense of estrangement from God, humanity and self; and even a disembodiment from oneself. And yet, from the perspective of those who are particularly frail in our society and communities, those who are deliberately and systematically excluded, absent resources, solidarity and love, and the everpresent violations of dignity and opportunity are existential realities. Simultaneously, the imagination of the absence of violence and indignity and the tangible presence of solidarity and humanity is the hope that erupts in the midst of frailty when the wisdom of the laboratory has reached its limitations.

\section{Frailty, the laboratory and confinement}

Foucault (1965:40-41), in Madness and Civilization, refers to the Hôpital Général that was created in Paris for people with mental illness problems. However, asserts Foucault (1965), the functioning of this hospital:

... had nothing to do with any medical concept. It was an instance of order, of the monarchical and bourgeois order being organized in France during this period. It was directly linked with the royal power which placed it under the authority of the civil government alone. (pp. 40-41)

For Foucault (1965:40), it is clear that the Hôpital Général was 'not a medical establishment'. In the 17th and 18th century all over Europe, certain categories of frailty were banished to confinement. Foucault (1965:64-65) refers to the work of philanthropist John Howard who discovered signs of this in England, Holland, Germany, France, Italy and Spain. He discovered that the same walls could contain those condemned by common law, young men who disturbed their families' peace or who squandered their goods, people without profession, and the insane' (Foucault 1965:40).

Hospitals and prisons both became places of confinement to maintain societal order and to remove frailty and ill discipline 
from the public eye. These were all the new lepers (Foucault 1965:45), and it became the social sensibility of the time.

The demand for confinement was both moral and economic (Foucault 1965):

Between labor and idleness in the classical world ran a line of demarcation that replaced the exclusion of leprosy. The asylum was substituted for the lazar house, the geography of haunted places as in the landscape of the moral universe. The old rites of excommunication were revived, but in the world of production and commerce. It was in these places of doom and despised idleness, in this space invented by a society which had derived an ethical transcendence from the law of work, that madness would appear and soon expand until it had annexed them. (p. 57)

Confinement was also a way of escaping shame and dishonour. Foucault (1965:67) quotes Malesherbes who defended confinement as the right of families to protect their honour.

University campuses might very well represent the laboratories of sanity whilst the frail - children, homeless and mentally ill - are confined out of sight. They do not make an economic contribution, they disturb the order and they bring shame. Universities are training grounds for economic prosperity, orderly behaviour and honour and prestige.

Until we awaken rudely to the fact of our own frailty - as custodians of both laboratory and asylum - we seek to remove frailty from the public eye, but too soon, we discover it in our own bodies and souls.

\section{Dis-membered bodies}

It is often at this point that we discover how dis-membered we are. Our own frailty becomes traces or signs of how we are absent from ourselves, from our intimate partners, from 'the other' and the 'Other' - dismembered, disconnected and 'unwhole' (see Palmer 2004).

Our world has become a collective of dis-membered bodies. To be dismembered is to be scattered in pieces, the result of a violent act or deep, painful cruelty. Landmines and bombs cause limbs to be dismembered. The human community is a dismembered body - scattered as rich and poor, literate and illiterate, mentally disabled and mentally superior, ethnically divided, women and men, children and the aged.

Gender, class, power and racial constructs have caused deep fragmentation, not only psychologically but also physically. There are those running the laboratories and the asylums, and those who are the perpetual patients - objects of scrutiny and dissection. Our scrutiny of each other further dismembers. It represents a violation of the dignity of the other. It is such violence that breeds violence (Fanon 1965a, 1965b).

The city is dismembered - inner-city neighbourhoods, suburbs, townships and informal settlements, often deeply segregated, the one becoming a no-go area of the other, in opposition to each other and perpetual strangers of each other. The landless and homeless, the refugees and asylumseekers find the city as a whole to be hostile territory, a place of banishment. The city seen in this way has a very close resemblance to a battered woman, in the words of Russell (1992:152-155).

Creation is a dismembered woman - scarred from head to toe, exploited for selfish benefits, discarded and wasted, clinging on for mere survival. The natural resources of the earth, the destruction of rivers and forests, the inaptitude with which waste is managed, the huge impact humans have on the environment and the environment on humans, the vicious cycles of decay and death dealt each other are leaving permanent scars, a body that cries out with constant groans to be set free from its decay (Boff 1995; Rm 8:21-22).

Different publics are dismembered: Academia, churches, communities, business and government are all functioning in opposition and contrast to each other, most of the time, instead of fostering creative collaborations that are urgently demanded by the collective cries of the poor and the earth together. The inability of different publics to find common languages, compelling and collaborative visions and innovative ways of optimising meagre resources mediate grave injustices to all publics concerned but particularly to those most vulnerable members of the general public.

The church is a dismembered body - functioning for years in the same neighbourhood without speaking to each other, without eating at the same table whilst confessing to membership of one family. The church is failing to work in coordinated ways although we are supposedly one body, seriously dismembered and disfigured, impotent from generating life and growth in dying neighbourhoods.

Our dis-embodiment is often profoundly accentuated on a university campus in its dis-connection from the frailty of our city. Although less obvious than in Gugulethu or Langa, Hillbrow or Alexandra, it is the hidden frailty of the laboratory, the frailty of the custodians of the university, if less hidden and more expressed, that could become the bridge between city and university. It is in our common experience of suffering or frailty that we might best be able to discover and express our common humanity. It is in our own embodiment of frailty, even if by default, that we will find bridges to 'the other'.

\section{The 'absent presence' or 'present absence' of God}

The hidden God, a Creator who abandoned his own creation, is often contemplated theologically. Yet, Dingemans (1990: 8-9) argues, there is something liberating in departing from the too obvious presence of God and in accepting the obvious absence of God. 'God is aanwezig als de verborgene, de niet manipuleerbare, de ongrijipbare, de reopened' (Dingemans 1990:9).

It is a departure from a notion that this God too can be subjected to the scrutiny of the 'laboratory', that is, the 
possibility to detain, to contain, to manipulate, to dissect and to understand One who is essentially mysterious - invisible presence, absent presence (cf. Dingemans 1990:20).

The surprise of the hidden God in the biblical tradition is that God cannot be defined or reached, in the words of Dingemans (1990:29), and yet God 'appears' - to Moses in the burning bush and throughout the desert, to the prophets in exile - as signs of God's 'verborgen aanwezigheid' [hidden presence].

Dingemans (1990:29) suggests the development of a pneumatology in theology that will take the absence of God and the presence of God equally serious, not only discovering signs of the hidden God present in the biblical tradition but also in the movements of our time. Dingemans (1990:30) speaks of those who have discerned the hidden God in their own situations, particularly in movements of liberation such as black, feminist and liberation theologies, in the landless people's movements and in the campaigns for access to antiretroviral medication.

In the New Testament, Jesus was identified particularly with those strangers who were imprisoned, homeless and orphaned - the ones typically prohibited from sanitised spaces, in those times, and today too - the Gautrain stations, upmarket shopping malls or university campuses. Should we fail to nurture a 'practical pneumatology', discerning God's presence in the stranger, perpetuating the exclusion of the stranger or failing to discover the mysteries of God in the arts or sciences, the mediated God will remain elusive (cf. Dingemans 1990:36, 38).

It is perhaps part of the liberating gift of practical theology on a university campus to wrestle with the presence and absence of frailty in concrete ways. Theology is namely never valuefree, objective or neutral (cf. Dingemans 1990:88). Dingemans (1990:20) proposes that the consensus of mainstream practical theology is in its focus on Christian praxis, namely reflective practice, reflective actions and the study of those actions, as they are expressed in and through the church, in the healing and liberation of suffering people and in the liberation of the world.

Should the liberation of suffering people and the world be such a central category in the work of practical theology, so should be its deep connectedness to the margins. However, the 'margins' are often not 'present' at the 'centre' of our theological work, or, looking at it from so-called marginal places, the academy itself is perhaps what is marginal in its sanitised laboratory existence that often disconnects itself from the multiple 'centres' of a suffering humanity. What is perhaps required are theological movements of juxtaposition, reversal and subversion, intentionally re-locating itself into 'centres' of human suffering to overcome the marginality of the theological enterprise in order for it to help facilitate the liberation of marginal peoples and neighbourhoods.
God often appears in the frailty of the cross or the stranger, the child or the outcast. He does so not only to show us the faces of frailty and invite us to embrace it in our own bodies but also to let it be mirrors to our own frailty, unmasking the frailty within, helping us to come face to face with ourselves.

God can be restricted to neither laboratory nor asylum. God occupies the mysterious, surprising, in-between, present and absent spaces which we seek to define carefully or for which we create boundaries. In the difference, God is transcending the false oppositions to practice a radical hospitality, creating liberating encounters with 'the other' - strangers and lepers and homeless - as the on-going opportunities to meet the Other. Exploring these mysterious encounters is a central part of the vocation of practical theology. It is in these surprising spaces where God turns suffering realities into studios of life, for example the Potter of Jeremiah 18, remaking what is broken.

\section{On remembrance}

I was sitting in the hall of Integrated Holistic Approach Urban Development Project (IHA/UDP) in Addis Ababa, an amazing grass-roots organisation journeying with slum dwellers of that great city. The banner on the wall of the conference venue simply read: 'Remember the poor' taken from the letter to the Galatians 2:10.

It struck me that it might not be such a passive remembrance that is required of us. It might not be a simple stroll down memory lane but rather an invitation to the very delicate, deliberate, daring and thoroughly painstaking work of remembering dis-membered bodies, dis-membered cities, a dismembered human community, a dis-membered creation.

The task of re-membering is a deliberate resolve to undo the work of dis-membering. Instead of blowing apart into scattered wounded pieces, the task of re-membering is to put back together again, to bind the wounds, to mend the brokenness, to make whole the scattered (cf. also Benjamin in Ward). Différance, in Derrida (1981:28), is the systematic play or traces of difference. Différance, examined theologically, becomes the play between the presence and the impossibility of God (Ward 1995:232).

Ward (1995:233), in the context of the absent or hidden God, wonders whether différance as used by Derrida, can be used to describe what takes places in Jesus Christ as the mediating Word, the mark and the traces.

The first phase or task of deconstruction, according to Derrida (1981:41-42), is to overturn oppositions (Wikipedia n.d.[c]):

To be effective, and simply as its mode of practice, deconstruction creates new notions or concepts, not to synthesize the terms in opposition, but to mark their difference, undecidability, and eternal interplay.

The act of remembrance is the embrace of différance to overcome absence and presence oppositions. It is the very deliberative act(s) of allowing and becoming sign or 
representation whilst at the same time making space for frail and excluded voices to represent themselves (cf. Derrida 1981:30). Foucault (2006) accused Derrida of practicing:

... a historically well-determined little pedagogy ... which teaches the student that there is nothing outside the text ... A pedagogy which inversely gives to the voice of the masters that infinite sovereignty that allows it indefinitely to re-say the text. (pp. xxiv, 573)

As long as our representations are mere fake simulations without the messy, physically embodied disruptions of slums and streets into our laboratory existences, re-membering will remain a philosophical endeavour instead of the deeply liberating work expected of us.

\section{Memory in remembrance}

The task of remembrance could be illumined by considering the contribution of Giambattista Vico (1668-1744) on memory:

Memory thus has three different aspects: memory when it remembers things, imagination when it alters or imitates them, and invention when it gives them a new turn or puts them into proper arrangement and relationship. (Vico 1968:19)

Memory consists of itself (memoria), imagination (fantasia) and invention (ingegno) (Verene 1981:96-97). In Vico, these three memories are inseparable and mutually complementary (Verene 1981:101-102). Theological poets spoke of memory as the mother of Muses (Verene 1981:96-98), the art of practical wisdom.

Memory as memoria (Verene 1981:104) is the power to bring to the mind what is not before the mind, to find in the here the not-here and in the now the not-now. Remembering the poor in this sense would mean to bring to mind the most vulnerable of society that is not before the mind, to find in the here those who are not here and in the now those people, places and preferred future realities that are not with us now.

Verene (1981:102) suggests memory as fantasia as the recollective, creative imagination and the basis of philosophical thought instead of reflection and speculation. Imagination (fantasia) is the form of memory with the ability to mentally reorder what has been recalled through memoria, to give what has been recalled human form in a way that seems familiar, tangible and accessible (Verene 1981:104). Remembering in this sense will include re-presenting in new ways, in and through new structures, new epistemologies and new locations. It will empower a deep connection between university and city, creating new spaces between and beyond laboratory and asylum. It goes beyond rational knowledge and invites the transcendent into our spaces of reflection and consideration.

Evoking imagination in the spaces between presence and absence, theology and frailty, university and city has the potential to open up radical new possibilities for gaining knowledge and for fostering truly humane urban spaces and places (cf. also Harvey Cox's 1969 The Feast of Fools: A Theological Essay on Festivity and Fantasy).
Memory as invention (ingegno) is the work of translating memory as memoria and fantasia through proper relationships or arrangements, making meaning, forming sensations, allowing experiences (Verene 1981:104).

Reconstructive fantasia may give access to physical truth but is actually operating at a metaphysical level (Verene 1981:125). Memory as invention or ingegno translates metaphysical reimagination into physical - and spatial - reconstruction.

Ward (1995:90) refers to Barth, suggesting that our memory of God is one of absence. It is the 'memory of a lost relationship with God', and therefore, 'it is a memory that invokes desire' (Ward 1995:90) or beautifully phrased by Barth as 'the longing for the recovery of the lost immediacy of my life in God'. Strangely Barth has a positive embrace of the absence of God but a negative view of the imago Dei (Ward 1995:90) as it is a constant reminder 'of always and only having mediation'.

\section{In the studio of life: Re-membering beyond laboratory and asylum}

Unlike the sanitised space of the laboratory or the confined space of the asylum, the studio is an expressive space, often drawing from the raw ingredients of the earth and the conflicting experiences of life to discover, imagine, design and create within and in response to the realities of life, namely a piece of art. The studio of the potter is messy but creative, the studio of the jazz musician is a practice of improvisation and the studio of the dancer is a vibrant and passionate expression of the deepest emotions captured in the soul (Wikipedia n.d.[d]):

A studio is more or less artful to the degree that the artist who occupies it is committed to the continuing education in his or her formal discipline. Academic curricula categorize studio classes in order to prepare students for the rigors of building sets of skills which require a continuity of practice in order to achieve growth and mastery of their artistic expression. A versatile and creative mind will embrace the opportunity of such practice to innovate and experiment, which develops uniquely individual qualities of each artist's expression. Thus the method raises and maintains an art studio space above the level of a mere production facility or workshop.

The word studio ' ... is derived from the Italian: studio, from Latin: studium, from studere, meaning to study or zeal' (Wikipedia n.d.[d]).

The dancer and the painter would be stifled by the laboratory. It is rather often the asylum, the exclusion, the estrangement of the artist that makes the studio a space of such deep connectedness with the universal reality of human frailty. Allowing the asylum to be tempered with a discipline and rigour not dissimilar to that of the laboratory but different in its invitation of chaos and its rootedness in life, the studio becomes a liberating space, a space of critical reflection and imaginative action, mediating différance, transcending the binary opposition of laboratory and asylum and becoming the liberating space of mutuality. 
Art Erickson, after working in the trenches of inner-city Minneapolis for 40 years, finally retired as the founding director of Urban Ventures, a grass-roots community foundation committed to urban regeneration and social inclusion. Instead of withdrawing from public life, he created STUDIOne-Eighty, training urban transformational leaders in the studio of urban life, drawing from the realities of inner-city challenge and change, reflecting deeply and imaginatively on possible preferred realities and developing innovative responses for urban change (see Urban Ventures 2013). Neither laboratory nor asylum, the studio provides an innovative space for transformational education, inviting urban frailty and own frailty to creatively connecting and imaginatively transcend current constraints and slaveries to foster new and transformative practices.

\section{Re-membering: Making absence present}

The first task of re-membering is for absence to be(come) intrusive, in our minds, in our consciences and conversations, in our re-membering. It is the task of memoria (Verene 1981:104). The important task of re-membering will include mediating presence through traces and signs of the presence which are not immediate but also through physical presence. One can hide behind the Derridean notion of absence and presence, but the stranger without a voice would rather be present in person than be interpreted by a foreign and handsoff scholar.

Abahlali baseMjondolo (Abahlali baseMjondolo n.d.) has located itself on Kennedy Road in Durban, organising landless people to claim their rights. Their visible presence became a powerful tool in defying and subverting the efforts to displace the poor into obscurity. Their unsettling presence helps to call into memory those who are not immediately present and also those who are deliberately made to be absent. When they speak of the 'university of Abahlali', it refers to their very visible, physical and disturbing presence that seeks to re-educate academics, activists and non-profit leaders, insisting that those of us who seek to mediate transformation need to be transformed first by the very real experiences of those living with the violence of poverty, being victims and agents at the same time.

Through the stranger we may have something of the unsettling Spirit brought into our domesticated lives (Palmer 1997:57). We are much more comfortable with the settled nature of things, and therefore we embrace the practice of domestication much more readily than the practice of liberation. We are used to domesticated Black people, domesticated women, domesticated students, domesticated children, domesticated laity, domesticated workers, all being subjugated to those with greater power and resources. We make them to be like us. A practice of liberation will facilitate liberated agents of change, with a deep sense of consciousness, ready to question and disturb. Universities can easily fall into the trap of becoming schools of domestication, instead of inviting very deliberately a multiplicity of voices that will help foster a new praxis of liberation.
Palmer (1997:57-58) draws from the story of Abraham and Sara and the story of Jesus and the Emmaus travellers, saying that 'both stories tell us that our everyday perceptions and assumptions must be shaken by the intrusion of strangeness if we are to hear God's word'.

Palmer (1997:64) suggests that, in Jesus' ministry, the stranger has a particular identity:

... he or she is one of those who suffer most, who is among the lowliest and most outcast of society. In this view the stranger is not simply an individual, but who represents an entire class of people who are pressed to the bottom layer of our world.

All of these are objects of fear, a fear which runs so deep we have invented entire institutions to keep such folk 'out of sight, out of mind'. In fact, all of these people are strangers. It is their strangeness which puts us off; we are estranged from all of them. (pp. 64-65)

Palmer (1997:65) suggests that the stranger is not only those who need us, but we need the stranger if we want to know God.

The symbol and sacrament of Holy Communion is making the absence of God present through earthly tokens of bread and wine. The mystery of the hidden God becomes present, and humanity connects and reconnects to God, self, others and creation through the simplicity of sharing a meal. Ward (1995:231) speaks of it as 'a ritual of absence and departure and a ritual of presence and incorporation'.

We probably need to create many different ways of illuminating absence, of letting it speak, of embracing its power to transform. We need to create spaces, curricula, rituals and conversations that will practice memoria.

\section{Re-membering: The fragile work of reweaving}

The second aspect of memory in Vico (Verene 1981:104) refers to imagination (fantasia). Re-membering goes beyond memory as memoria but becomes active in imagining the painful, fragile but creative process of reweaving, of bringing together all the scattered pieces, of making whole what is broken apart.

It requires intra- and interdisciplinary collaborations with various publics and civil society, with strangers in different cloaks and colours, with artists and musicians and poets to imagine the unimaginable, to see visions and dream dreams of rewoven fabrics where now there are only fractures.

Foucault (1965:289) refers to the work of artists saying, 'where there is a work of art, there is no madness'. In their moments of greatest agony, creativity expresses itself in the works of Van Gogh, Nietzsche and others (Foucault 1965):

... by the madness which interrupts it, a work of art opens a void, a moment of silence, a question without answer, provokes a breach without reconciliation where the world is forced to question itself. (p. 288)

It is precisely the madness which we want to control or contain that is allowed to cut into the absences, making 
present a void, a silent cry, a memory, a mirror. It is becoming a representation not just of the frailty of the other but of our own. It is helping us re-member our frailty to the frailty of others, enabling us to start the careful and fragile work of reweaving. Where that happens, what is perceived as madness becomes the sanity of new imagination.

The meal of remembrance in the Christian faith is also such a task of turning madness into sanity. It is about doing the fragile work of reweaving - sinners and sinned against, victims and perpetrators, wounded and whole, enslaved and free. It is the madness of the cross interrupting our daily lives to open a void, a moment of silence, a mirror - inviting us to collaborate in this fragile work of reweaving. It is stirring us to fresh imaginations of radically altered realities.

How do we allow interruptions of the cross, madness, homelessness, children's laughter, clown and satirist to break into the laboratory and sanity of a university campus in ways that will provoke 'a breach ... where the world is forced to question itself' (Foucault 1965:288)? How do we allow such interruptions to become representations and remembrances that will transform our presence and absence into a commitment to reweave dis-membered bodies?

Could it perhaps also be that the university campus needs to be dislocated with intentionality in order to be re-located in ways and in places that will facilitate the transformation of university and city - alike? Could the dis-location and subsequent re-location be the process of possible re-imagined realities and rewoven, re-worked, preferred possibilities?

\section{Re-membering: The politics of radical hospitality}

The third element of memory in Vico (Verene 1981:104) is that of ingegno or invention. The laboratory, at its best, is not just a sterile environment for dissecting the dead but is also supposed to be a space of invention. I suggest spaces of radical hospitality as the kind of spaces potent for such invention. Can practical theology and other disciplines practice a politics of radical hospitality which will allow asylum and laboratory to meet in newly invented spaces, through new curricula, learning exchanges and teaching methodologies?

Can the frailty and expertise of 'insider' and 'outsider', of 'teacher' and 'student', of 'therapist' and 'patient', of 'researcher' and 'researched' be mediated through remembrance where both laboratory and confinement would be transcended, inventing and practising radical hospitality. Could these binaries be mediated through finding and making new spaces of différance where our shared brokenness is offered in ways that could mediate mutual learning and liberation, collective re-membering and re-weaving?

In spaces of radical hospitality, where the suffering of the city and the marginality of the university are allowed to meet creatively, presence and absence can be transcended, an alternative imagination can be nurtured and artistic interruptions and inventions that will alter and transform both city and university alike can be invited.

Recently I had the privilege of facilitating a workshop on community development with 300 people from the informal urban settlement of Diepsloot. I had a profound sense that doing theology and academy together in such a space would alter the way we are, think and do, alone and together, in immeasurable ways, for current and future generations. Where the experts of the informal settlements - those longtime residents - meet with the academic 'experts', spaces of radical hospitality can occur that will enable imaginary (re-) inventions of the way we think, know, live and act. Spaces of radical hospitality will allow us to share our mutual frailty and not-knowing - and as we allow ourselves to be known, new freedoms will occur, and new ways of knowing will emerge.

Practical theology and the academy, in learning to practice a politics of radical hospitality, will run the risk of participating in new liberations and revolutions, not seen before. The question is, however: Is it willing to take such a risk? Practising a theology or a politics of radical hospitality will allow strangers to become teachers, frailty to invade our sterility and insanity to disturb our sanitised spaces. Where such hospitality occurs, new inventions of life, new solidarities, new ways of being human, new ways of being urban, new ways of practising justice and equity will break into what was known before.

Just as violence breeds violence in Fanon, such hospitality in multiple small spaces will breed hospitality in the greater polis, and the freedoms experienced and tasted at the newly created tables will breed new freedoms in society at large.

\section{Conclusion}

This article is in some ways a very personal reflection, recording my own journey from being in the womb of the inner city to being dis- or re-located to a university campus. Daily I journey in and between these different worlds. It represents my own (frail) desire to go beyond the presence and absence dichotomy in a search for new ways of being, doing and knowing, between university and city, between theology and the streets, between laboratory and asylum, where frailty is lived in the studio of life, where disembodied and dismembered realities groan for spaces and memories that will invoke, imagine and invent re-membered realities.

\section{Acknowledgements Competing interests}

The author declares that he has no financial or personal relationship(s) that may have inappropriately influenced him in writing this article. 


\section{References}

Abahlali baseMjondolo, n.d., Abahlali baseMjondolo, viewed 16 April 2013, from www.abahlali.org

Bell, A., n.d., Absence/presence, viewed 16 April 2013, from http://csmt.uchicago. edu/glossary2004/absencepresence.htm

Boff, L., 1995, Cry of the earth, cry of the poor, Orbis Books, Maryknoll, New York.

Cox, H., 1969, The feast of fools: A theological essay on festivity and fantasy, Harvard University Press, Cambridge.

Davis, M., 1992, City of quartz: Excavating the future in Los Angeles, Vintage, London.

Davis, M., 1992, 'Fortress Los Angeles: The militarization of urban space', in M. Sorkin (ed.), Variations on a theme park: The New American city and the end of public space, pp. 154-180, Noonday Press, New York.

De Beer, SF., 2008, 'Contesting inner city space: Global trends, local exclusion/s and an alternative Christian spatial praxis', Missionalia 36(2/3), 181-207.

Derrida, J., 1981, Positions, University of Chicago Press, Chicago. PMid:6910236

Dingemans, G.D.J., 1990, De tijd van de verborgen God: Verkenningen en reflecties, Boekencentrum, s'-Gravenhage.

Fanon, F., 1965a, The wretched of the earth, transl. C. Farrington, Grove Press, New York.

Fanon, F., 1965b, Concerning violence, Penguin Books, London.

Feder, EK., 2011, 'Power/knowledge', in D. Taylor (ed.), Michel Foucault: Key concepts, pp. 55-68, Acumen, Durham.

Foucault, M., 1965, Madness and civilization: $A$ history of insanity in the age of reason Random House, New York.

Foucault, M., 2006, History of madness, ed. J. Khalfa, transl. J. Murphy \& J. Khalfa, Routledge, London.
Foucault, M., 1979, Discipline and punish: The birth of the prison, transl. A. Sheridan, Random House, New York.

Merrifield, A. \& Swyngedouw, E. (eds)., 1997, The urbanization of injustice, New York University Press, New York. PMCid:PMC20359

Palmer, P., 1997, Company of strangers: Christians and the renewal of America's public life, Crossroad, New York.

Palmer, P., 2004, A hidden wholeness: The journey toward an undivided life, JosseyBass, San Francisco.

Russell, L., 1992, 'The city as battered woman', in E.S. Meyers (ed.), Envisioning the new city: A reader on urban ministry, pp. 152-155, John Knox Press, Westminster.

Urban ventures, 2013, Studione-eighty: Changing places ... Changing people ... 180 The Urban Ventures story, viewed 16 April 2013, from http://www.urbanventures. org/our-programs/studione-eightly.html

Verene, D.P., 1981, Vico's science of imagination, Cornell University Press, Ithaca \& London.

Vico, G., 1968, The new science of Giambattista Vico, transl. from Scienza Nuova [1725] by T.G. Bergin \& M.H. Fixch, Cornell University Press, Ithaca.

Ward, G., 1995, Barth, Derrida and the language of theology, Cambridge University Press, Cambridge.

Wikipedia, n.d.(a), Laboratory, viewed 16 April 2013, from http://en.wikipedia.org/ wiki/Laboratory

Wikipedia, n.d.(b), Trace (deconstruction), viewed 16 April 2013, from http:// en.wikipedia.org/wiki/Trace_(deconstruction)

Wikipedia, n.d.(c), Jacques Derrida, viewed 16 April 2013, from http://en.wikipedia. org/wiki/Jacques_Derrida

Wikipedia, n.d.(d), Studio, viewed 16 April 2013, from http://en.wikipedia.org/wiki/ Studio 